\title{
Farklı Azotlu Gübreler ve Uygulama Zamanlarının Buğdayda Verim ve Verim Komponentlerine Etkileri
}

\author{
Mahmut TEPECIK ${ }^{*}$ \\ N. Tuba BARLAS 1 \\ Emre İLKER² \\ 'Ege Üniversitesi Ziraat Fakültesi Toprak Bilimi ve Bitki Besleme Bölümü, İzmir \\ ${ }^{2}$ Ege Üniversitesi Ziraat Fakültesi Tarla Bitkileri Bölümü, İzmir
}

\begin{abstract}
*Sorumlu yazar e-posta (Corresponding author e-mail): mahmut.tepecik@ege.edu.tr Geliș tarihi (Received) : 11.10.2013

Kabul tarihi (Accepted) : 17.02.2014
\end{abstract}

\section{Öz}

Çiftçi koșullarında yapılan bu çalıșmada gübrelemenin öneminin gösterilmesi amaçlanmıștır. Bu çerçevede Aydın-Söke'de (37041'18" N ve 27022'56" E) yürütülen bu denemede, ekmeklik buğday çeșidi Golia (Triticum aestivum L. cv.)'ya farklı azotlu gübreler taban, üst ve taban+üst gübre olarak uygulanmıștır. Taban gübrelemesinde diamonyum fosfat (DAP) ve 20.20.0; üst gübrelemede ise kalsiyum amonyum nitrat (CAN) ile amonyum nitrat (AN) gübreleri uygulanmıștır. Uygulamaların verim ve verim komponentlerine (bitki boyu, bașak uzunluğu, bașaktaki tane sayısı, bașak tane ağırlığı ve bin tane ağırlığı) olan etkileri belirlenmiștir. En yüksek verim taban ve üst gübre (taban + üst) uygulamasının birlikte yapıldığı gübre uygulamasından elde edilmiștir.

Uygulamalar içerisinde tam doz 20.20.0 uygulaması ile en yüksek bitki boyu $(60.56 \mathrm{~cm})$, bașak uzunluğu (6.24 cm), bașaktaki tane sayısı (33.69 tane/bașak), bin tane ağılığı (37.46 g) ve verim (747 kg/da) elde edilmiștir. İncelenen parametreler açısından taban gübrelemesinin yapıımadığı, yalnızca üst gübrelemenin yapııdığı (Taban0 + ÜstN) uygulamasından, kontrole benzer sonuçlar elde edilmiștir.

Anahtar Kelimeler: Azot, buğday, gübre, kalite, verim.

\section{Effect of Application Time and Different Nitrogen Fertilizer on Yield and Yield Components of Wheat}

\begin{abstract}
The present study was conducted with the aim of demonstration of importance of application time and source of different nitrogen fertilizers. In this respect fertilization trial carried out under farmer

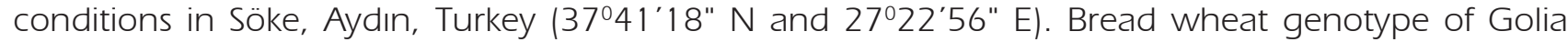
(Triticum aestivum L.) was used as plant material. Diammonium phosphate (DAP) and 20.20.0 were used as basic fertilizers and calcium ammonium nitrate (CAN) and ammonium nitrate (AN) were used as top dressing. Effects of fertilizer treatments on yield and yield components (plant height, spike length, number of kernel per spike, kernel weight per spike, thousand-kernel weight) were evaluated.

The highest values were obtained from basic + top dressing application. In this context full-dose 20.20 .0 yielded higher plant height $(60.56 \mathrm{~cm})$, spike length $(6.24 \mathrm{~cm})$, number of kernel per spike (33.69), thousand-kernel weight $(37.46 \mathrm{~g})$ and yield $(747 \mathrm{~kg} / \mathrm{da})$ than the other treatments. In respect to investigated parameters, only top dressing, without basic fertilization (Basic0+TopN) treatment yielded similar results with the control.
\end{abstract}

Key Words: Nitrogen, wheat, fertilizer, quality, yield 


\section{Giriș}

Buğdayın tüm dünya ülkelerinde ana beslenme kaynaklarından biri olması, buğdaya stratejik bir ürün olma özelliği kazandırmaktadır. Buğday insan beslenmesi için gerekli olan kalori ve proteinin önemli bir kısmını karșılamakta olup dünya nüfusunun \% 35'ini olușturan yaklașık 40 ülkenin temel gıdasıdır (Kendal vd., 2012). Buğday, dünyada ve ülkemizde gerek ekiliș, gerekse üretim miktarı bakımından ilk sırada yer alan ve insan besini olması yanında, hayvan beslenmesinde de kullanılan önemli bir kültür bitkisidir (Mut vd., 2007).

Geniș bir adaptasyon yeteneğine sahip olan buğday ülkemizin hemen hemen bütün bölgelerde yetiștirilmektedir. Dünyanın birçok ülkesinde olduğu gibi ülkemizde de günlük kalorinin önemli bir kısmı tahıl ve tahıl ürünlerinden sağlanmaktadır (Özer, 1998). Tahıl terimi "Gramineae" familyasının tohumları olan buğday, mısır, çavdar, çeltik, arpa, yulaf, kușyemi ve darı gibi tanelerin tümünü ifade etmek için kullanılır (Altan, 1986). Ayrıca, kolay yetiștirilmesi, toplumların sahip oldukları beslenme alıșkanlıkları ve çok yönlü kullanım imkanı ile önemli yer tutmaktadır (Pyler, 1988).

Protein içeriği buğday kalitesini belirlemede önemli kriterlerden birisidir (Atlı vd., 1999). Buğdayda protein miktarının tür, çeșit, çevre koșulları ve üretim tekniğine bağlı olarak \% 6-22 arasında değiștiği ve ülkemizde protein miktarının ekmeklik buğdaylarda \% 10-15 ve makarnalık buğdaylarda ise \% 11-17 arasında değiștiği bildirilmiștir (Ünal, 2002). Tane protein içeriğinin buğdayda önemli bir kalite kriteri olduğu, tane protein içeriği kadar protein kalitesinin de önemli olduğu ve azotlu gübreleme zaman ve dozunun bu bağlamda çok önemli bir faktör olduğu belirtilmektedir (Fageria vd., 1997; Triboi vd., 2000).

Ülkemizde gübre fiyatlarının yükseldiği yıllarda çiftçilerin gübre uygulamalarından kaçındıkları, böylesi yıllarda çiftçilerin ya taban gübreleme veya üst gübrelemeden birini tercih ettikleri ve uygulanması gereken dozların çok altında gübre uyguladıkları izlenmektedir. Uygulama zamanı ve dozları açısından optimumun dıșına çıkıldığında, ortaya çıkacak sonuçları izlemenin ve bunların pratikte çiftçilere aktarımasının yararlı olacağı düșüncesi ile bu çalıșma düzenlenmiștir.

Çalıșmada farklı azotlu gübrelerin farklı zamanlarda (taban ve üst) uygulanmasının buğdayda verim ve verim komponentlerine etkisi incelenmiștir. Bu bağlamda Söke'de çiftçi koșullarında yürütülen bu denemede materyal olarak Golia ekmeklik buğday çeșidiyle taban gübresi olarak DAP ve 20.20.0, üst gübresi olarak kalsiyum amonyum nitrat (CAN) ve amonyum nitrat (AN)'ın farklı gübre kombinasyonları kullanılmıștır.

\section{MATERYAL VE YÖNTEM}

Deneme, Söke-Aydın'da çiftçi koșullarında ve kuru tarım uygulanan bir tarlada yürütülmüștür. Deneme alanına ilișkin iklim verileri ve toprak özellikleri Çizelge 1 ve 2'de verilmiștir.

C̣izelge 1. 2009-2010 üretim yılında çalıșma alanına ait yağıș (mm) ve sıcaklık değerleri $\left({ }^{\circ} \mathrm{C}\right)($ Anonim, 2010).

Table 1. Rainfall (mm) and temperature $\left({ }^{\circ} \mathrm{C}\right.$ ) belong to study area in 2009-2010 growing season (Anonoymous, 2010)

\begin{tabular}{|c|c|c|c|c|c|}
\hline & & $\begin{array}{c}\text { Aylık ortalama } \\
\text { sıcaklık }\left({ }^{\circ} \mathrm{C}\right) \\
\end{array}$ & $\begin{array}{l}\text { Aylık minimum } \\
\text { sıcaklık }\left({ }^{0} \mathrm{C}\right)\end{array}$ & $\begin{array}{c}\text { Aylık maksimum } \\
\text { sıcaklık }\left({ }^{0} \mathrm{C}\right)\end{array}$ & $\begin{array}{c}\text { Aylık toplam yağıș } \\
(\mathrm{mm})\end{array}$ \\
\hline \multirow{6}{*}{$\stackrel{\circ}{\circ}$} & Ocak & 10.0 & -2.3 & 21.7 & 204.8 \\
\hline & Șubat & 11.8 & -2.6 & 22.2 & 249.2 \\
\hline & Mart & 13.4 & 2.5 & 24.6 & 12.0 \\
\hline & Nisan & 17.1 & 6.6 & 29.8 & 7.8 \\
\hline & Mayıs & 21.9 & 10.5 & 41.5 & 19.2 \\
\hline & Haziran & 24.9 & 16.1 & 39.9 & 9.2 \\
\hline \multirow{2}{*}{ 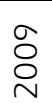 } & Kasım & 14.3 & 4.2 & 24.1 & 91.7 \\
\hline & Aralık & 12.3 & 4.2 & 21.0 & 148.2 \\
\hline
\end{tabular}


Çizelge 2. Deneme toprağının fiziksel ve kimyasal özellikleri

Table 2. Physical and chemical characteristics of experiment soil

\begin{tabular}{|l|c|c|}
\hline $\mathrm{pH}$ & & 7.20 \\
\hline Toplam tuz & $(\%)$ & 0.048 \\
\hline Kirec & $(\%)$ & 17.86 \\
\hline Kum & $(\%)$ & 77.28 \\
\hline Mil & $(\%)$ & 16.00 \\
\hline Kil & $(\%)$ & 6.72 \\
\hline Bünye & $(\%)$ & 1.91 \\
\hline Organik madde & $(\%)$ & 0.045 \\
\hline Toplam N & $\left(\mathrm{mg} \mathrm{kg}^{-1}\right)$ & 6.20 \\
\hline Alınabilir $\mathrm{P}$ & $\left(\mathrm{mg} \mathrm{kg}^{-1}\right)$ & 174.20 \\
\hline Alınabilir K & $\left(\mathrm{mg} \mathrm{kg}^{-1}\right)$ & 3576 \\
\hline Alınabilir Ca & $\left(\mathrm{mg} \mathrm{kg}^{-1}\right)$ & 161.4 \\
\hline Alınabilir $\mathrm{Mg}$ & $\left(\mathrm{mg} \mathrm{kg}^{-1}\right)$ & 36.60 \\
\hline Alınabilir $\mathrm{Na}$ & $\left(\mathrm{mg} \mathrm{kg}^{-1}\right)$ & 9.20 \\
\hline Alınabilir Fe & $\left(\mathrm{mg} \mathrm{kg}^{-1}\right)$ & 0.80 \\
\hline Alınabilir Zn & $\left(\mathrm{mg} \mathrm{kg}^{-1}\right)$ & 1.90 \\
\hline Alınabilir Cu & $\left(\mathrm{mg} \mathrm{kg}^{-1}\right)$ & 5.40 \\
\hline Alınabilir $\mathrm{Mn}$ & & \\
\hline
\end{tabular}

Tesadüf blokları deneme desenine göre, 3 tekrarlı olarak yürütülen denemede; kısa boylu ve erkenci özelliklere sahip olan Golia ekmeklik buğday çeșidi kullanıımıștır. Denemenin yürütüldüğü parsel boyutları $18.5 \mathrm{~m} \times 2.3 \mathrm{~m}\left(42.55 \mathrm{~m}^{2}\right)^{\prime}$ dir. Parseller arasında $30 \mathrm{~cm}$ 'lik rantlar bırakılmıștır.
Taban gübre uygulaması 2009 yılında Ekim ayının son haftasında ve ekim ile birlikte tohumların 4-5 cm altına gelecek șekilde mibzer ile yapılmıștır. Denemede iki üst gübre uygulaması yapılmıștır. Birinci üst gübreleme kardeșlenme dönemi sonlarına doğru, ikinci üst gübreleme sapa kalkma döneminde ana sapta ikinci boğum görüldüğünde yapılmıștır.

Taban gübrelenmesinde DAP (18.46.0) ve 20.20.0, birinci üst gübrelemede CAN (\% 26 N), ikinci üst gübrelemede ise AN (\% 33 N) kullanılmıștır. Deneme planı ve denemede kullanılan gübre ve miktarları Çizelge 3'de verilmiștir.

Hasat tanede su oranının \% 14'ün altına düștüğü ve bașakların tam olgunlaștığı dönemde (Haziran 2010) biçer-döver ile yapılmıștır. Her parsele ait bitki boyu $(\mathrm{cm})$, bașaktaki tane sayısı (adet/bașak), bașak tane ağırlığı (g/bașak), bașak uzunluğu $(\mathrm{cm})$ ve bin tane ağırlığı (g) hasattan hemen önce her parselden seçilen $1 \mathrm{~m}^{2}$ lik alandan alınan örneklerde belirlenmiștir (Yılmaz, 2003; Özseven ve Bayram, 2005). Tanede protein oranı Kjeldahl yöntemi ile belirlenen azot (N) miktarının 6.25 katsayısı ile çarpılması ile belirlenmiștir (Kırtok ve Genç, 1980; Gençtan ve Sağlam, 1987; Özkaya ve Kahveci, 1990).

Uygulamalara ait parsellerden alınan tane örnekleri kurutma ve öğütme ișlemlerinden sonra analize hazır hale getirilmiștir. Tanede N Kjeldahl yöntemine (Bremner, 1965) göre belirlenmiștir. Fosfor (P), potasyum (K), kalsiyum (Ca) ve magnezyum (Mg) ise nitrik-perklorik asit karıșımı ile yaș yakma yöntemi (4:1 $\left.\mathrm{HNO}_{3}: \mathrm{HClO}_{4}\right)$ ile elde

Çizelge 3. Denemede kullanılan gübreler ve miktarları $\left(\mathrm{kg} \mathrm{da}^{-1}\right)$

Table 3. Using fertilizers type and amounts in experiment ( $k g d a^{-1}$ )

\begin{tabular}{|l|l|l|l|l|l|}
\hline Uygulamalar & $\begin{array}{l}\text { Taban* } \\
\text { gübrelemesi }\end{array}$ & $\begin{array}{l}\text { 1. üst** } \\
\text { gübreleme }\end{array}$ & $\begin{array}{l}\text { 2.üst** } \\
\text { gübreleme }\end{array}$ & $\begin{array}{l}\text { Gübreden } \\
\text { gelen N }\end{array}$ & $\begin{array}{l}\text { Gübreden } \\
\text { gelen P }\end{array}$ \\
\hline Kontrol & 0 & 0 & 0 & 0 & 0 \\
\hline Yarım doz 20.20.0 & 20 & 20 & 0 & 9.20 & 4.00 \\
\hline Tam doz 20.20.0 & 35 & 20 & 15 & 17.15 & 7.00 \\
\hline DAP & 16 & 20 & 15 & 13.03 & 7.36 \\
\hline Taban o+ Üst $N$ & 0 & 20 & 0 & 5.20 & 0 \\
\hline
\end{tabular}

*Taban gübre: 20.20.0, ** CAN (\% 26 N), *** AN (\% 33 N)

${ }^{a}$ Bu uygulamada tam doz 20.20.0 uygulamasından gelen toplam $N$ ve P miktarlarının yaklașık yarısı oranında $N$ ve $P$ uygulandığı için; bu uygulama 'Yarım doz 20.20.0'olarak adlandırımıștır. 
edilen ekstraktta P kolorimetrik olarak (Lott vd., 1956), $\mathrm{K}$ ve Ca flamefotometrik olarak ve $\mathrm{Mg}$ ise Atomik Absorbsiyon Spektrofotometre (AAS) ile belirlenmiștir (Kacar ve İnal, 2008).

Deneme alanına (alüviyal) ait toprak örneğinde (0-30 cm); $\mathrm{pH} 1: 2.5$ toprak:su ekstraktında Jakson (1958)'e göre, kireç kalsimetrik olarak, organik madde Walkley-Black yaș yakma yöntemi ile, bünye hidrometre yöntemi ile, toplam N Kjeldahl yöntemi ile, bitkiye yarayıșlı $\mathrm{P}$ Olsen yöntemine göre spektrofotometrik olarak ve, alınabilir K, Ca ve Mg ise nötr $1 \mathrm{~N}$ amonyum asetat ekstraksiyonu $\mathrm{NH}_{4} \mathrm{OAc}(\mathrm{pH}=7)$ ile belirlenmiștir (Kacar, 2009).

Sonuçların istatistikî olarak değerlendirilmesinde varyans analizi uygulanmıștır. Ortalamaların karșılaștırılmasında LSD testi ( $\alpha: 0.05)$ kullanılımıștır (Açıkgöz vd., 1994).

\section{BULGULAR VE TARTIȘMA}

Uygulamaların Verim Komponentlerine Etkisi

Bitki Boyu: Uygulamaların bitki boyuna etkisi istatistiki olarak önemli bulunmuștur (Çizelge 4). artırdığı bildirilmiștir (Bașar vd. 1998). Denemede uygulamalara ait bitki boyları ile ilgili sonuçların, Golia buğday çeșidi için Gençtan ve Balkan (2006) tarafından verilen değerler ile uyumlu olduğu izlenmektedir. Buğdayda bitki boyunun çeșit, genetik yapı, ekim sıklığı, ekim zamanı, gübreleme, yağıș durumu ve toprak özelliklerine bağlı olarak değișebileceği rapor edilmiștir (Gençtan ve Sağlam, 1987; Doğan ve Yürür, 1992).

Bașak Uzunluğu: Uygulamalara ilișkin bașak boyları 4.45-6.24 cm arasında değișim göstermiștir (Çizelge 4). Tam doz 20.20.0 uygulaması (6.24 cm) ile diğer uygulamalara göre daha yüksek bașak boyu değerleri elde edilmiștir. En düșük bașak boyu ise kontrol uygulamasında $(4.45 \mathrm{~cm}$ ) belirlenmiștir. Golia çeșidinin diğer buğday çeșitlerine göre en kısa bașak uzunluğuna sahip çeșit olduğu belirtilmektedir (Gençtan ve Balkan, 2006; Turan, 2008).

Bașaktaki Tane Sayısı: Uygulamalara bağlı olarak 13.92-33.69 adet/bașak arasında değișmiștir (Cizelge 4). Tam doz 20.20.0 uygulamasında 33.69 adet ile en yüksek, kontrol uygulamasında ise 13.92

Çizelge 4. Farkı azotlu gübre kaynakları ve uygulama zamanlarının buğdayın verim ve bazı verim komponentlerine etkisi

Table 4. The effects of $N$ sources fertilizer and application times on wheat yield and yield components

\begin{tabular}{|l|l|l|l|l|l|l|}
\hline Uygulamalar & $\begin{array}{l}\text { Bitki } \\
\text { boyu } \\
(\mathrm{cm})\end{array}$ & $\begin{array}{l}\text { Bașak } \\
\text { uzunluğu } \\
(\mathrm{cm})\end{array}$ & $\begin{array}{l}\text { Bașaktaki tane } \\
\text { sayısı } \\
\text { (adet/bașak) }\end{array}$ & $\begin{array}{l}\text { Bașak tane } \\
\text { ağırlığı } \\
\text { (g/bașak) }\end{array}$ & $\begin{array}{l}\text { Bin tane } \\
\text { Ağırlığı (g) }\end{array}$ & $\begin{array}{l}\text { Verim } \\
\text { (kg/da) }\end{array}$ \\
\hline Kontrol & $41.40 \mathrm{~b}$ & $4.45 \mathrm{~b}$ & $13.92 \mathrm{c}$ & $\mathbf{0} \mathrm{b}$ & $29.93 \mathrm{~b}$ & $358 \mathrm{e}$ \\
\hline Yarım doz 20.20.0 & $59.47 \mathrm{a}$ & $5.99 \mathrm{a}$ & $32.35 \mathrm{a}$ & $1.16 \mathrm{a}$ & $37.02 \mathrm{a}$ & $619 \mathrm{~b}$ \\
\hline Tam doz 20.20.0 & $60.56 \mathrm{a}$ & $6.24 \mathrm{a}$ & $33.69 \mathrm{a}$ & $1.21 \mathrm{a}$ & $37.46 \mathrm{a}$ & $748 \mathrm{a}$ \\
\hline DAP & $59.67 \mathrm{a}$ & $5.78 \mathrm{a}$ & $30.13 \mathrm{a}$ & $1.07 \mathrm{a}$ & $37.22 \mathrm{a}$ & $558 \mathrm{c}$ \\
\hline Taban $0+$ Üst $\mathrm{N}$ & $46.16 \mathrm{~b}$ & $5.01 \mathrm{ab}$ & $17.49 \mathrm{~b}$ & $0.56 \mathrm{~b}$ & $30.28 \mathrm{~b}$ & $393 \mathrm{~d}$ \\
\hline LSD (0.05) & 5.22 & 1.30 & 13.92 & 0.477 & 3.90 & 18.52 \\
\hline
\end{tabular}

Çizelge 4' görüldüğü üzere, bitki boylarının tam doz 20.20 .0 uygulamasında $60.56 \mathrm{~cm}$, yarım doz 20.20.0 uygulamasında $59.70 \mathrm{~cm}$ ve DAP uygulamasında ise $59.67 \mathrm{~cm}$ olduğu saptanmıștır. En düșük bitki boyu $41.40 \mathrm{~cm}$ ile kontrol uygulamasından elde edilmiștir. Çiftçi ve Doğan (2013) Gediz-75 ve Flamura-85 buğday çeșitleri ile yaptıkları çalıșmada, en uzun bitki boyunun $\mathrm{N}$ uygulanan ve en kısa bitki boyunun ise $N$ uygulanmayan parsellerden elde edildiğini bildirmektedirler. Saraybosna buğday çeșidi ile yapılan bir gübre dozu denemesinde, artan azotlu gübre dozlarının bitki boyunu önemli düzeyde adet ile en düșük değerler elde edilmiștir. Bașaktaki tane sayısındaki bu farklııkların uygulamalara bağlı olarak tane bağlayan bașakçık sayısının artması ile ilgili olabileceği düșünülmektedir. Azotlu gübre dozunun artıșı ile tane bağlayan bașak sayısının artı̆̆ı Geçit ve Çakır (2006) tarafından da bildirilmiștir. Noaman ve Taylor (1990), Ekingezen (1996) ve Dokuyucu vd. (1999) tarafindan bașaktaki tane sayısı üzerine gübre formlarının etkili olduğu, Bașar vd. (1998) tarafından ise bașaktaki tane sayısı üzerine gübre formlarının önemli etkide bulunmadığını belirtilmiștir. 
Bașakta Tane Ağırlığı: Uygulamalara bağlı olarak bașak tane ağırıklarının 0.35-1.21 g arasında değiștiği saptanmıștır (Çizelge 4). En yüksek bașak tane ağırlığı tam doz 20.20.0 uygulamasında, en az ise kontrol uygulamasından elde edilmiștir. Azotlu gübre uygulamalarının bașakta tane ağırlığını etkilediği Gençtan ve Sağlam (1987) ve Avcı (2007) tarafından da bildirilmiștir.

Bin Tane Ağırığı: Denemede tüm uygulamala ra ait bin tane ağırlığı 29.93-37.46 g arasında değișmiș ve uygulamaların bin tane ağırlığına etkisi önemli düzeyde farklılık göstermiștir (Çizelge 4). En yüksek bin tane ağırlığı $37.46 \mathrm{~g}$ ile tam doz 20.200 uygulamasında, en düșük değer ise 29.93 $\mathrm{g}$ ile kontrol uygulamasında elde edilmiștir. Bașar vd. (1998) tarafından bin tane ağırlığı üzerine amonyum sülfat ve kompoze (25.5.0) gübrelerinin, üre ve amonyum nitrat gübrelerine göre daha etkili olduğu bildirilmiștir. Dogan vd. (2008) ise azot dozlarının bin tane ağırlığı üzerine olan etkisinin düzensiz olduğunu bildirmișlerdir. Isparta ekolojik koșullarına uygun yüksek verimli buğday çeșit ve hatlarının belirlenmesi amacıyla yapılan bir çalıșmada; Akman vd. (1999) bin tane ağırlığının 32-43 g arasında değiștiğini bildirmiștir. Araștırmamızdan elde edilen bin tane ağırlığı sonuçları, Mut vd. (2005)'nın belirttiği değerler ile uyumludur. Konu ile ilgili yapılan çalıșmalarda, genetik yapı ve ekolojik faktörlerin, buğdayda bin tane ağırlığı üzerine etkili iki önemli faktör olduğu, bașaklanma sonrası çevre koșullarından daha az etkilenen çeșitlerin bin tane ağırlığının yüksek olduğu bildirilmiștir (Korkut ve Ünay, 1987).

Verim: Denemede uygulamalara ilișkin verim değerleri 358-748 kg/da arasında değișmiș ve en yüksek verim tam doz 20.20.0 uygulamasından elde edilmiștir. En az verim ise kontrol uygulamasında elde edilmiștir (Çizelge 4). SümerÖzcan vd. (2010) tarafından yapılan bir çalıșmada, $665 \mathrm{~kg} / \mathrm{da}$ ile en yüksek verimin $16 \mathrm{~kg} \mathrm{~N} \mathrm{/} \mathrm{da}$ uygulamasından elde edildiğini bildirmiștir. Bașar vd. (1998) tarafından yapılan çalıșmada, buğdayda verim yönünden amonyum sülfat, amonyum nitrat ve üre gübreleri arasında önemli bir farkın olmadığı belirtilmiștir. Sümer (2008), azotlu gübrelerin buğdayda verimi artırdığını bildirmiștir.

\section{Uygulamaların Tanede Protein ve Besin Element İçeriğine Etkisi}

Tanenin azot ve protein içerikleri üzerine uygulamaların önemli düzeyde etkili olduğu saptanmıștır (Çizelge 5). Bu bağlamda, \% $2.27 \mathrm{~N}$ ve \% 14.20 protein içeriği ile en yüksek değerlerin DAP uygulanan parsellerden elde edildiği görülmüștür.

Uygulamalara bağlı olarak tanedeki protein oranının DAP > tam doz 20.20.0 > yarım doz 20.20.0> Taban 0+ Üst $N>$ kontrol șeklinde bir sıralama izlediği saptanmıștır. DAP uygulamasında daha yüksek tane protein içeriğinin belirlenmiș olmasının gübre formlarının etkinliklerine bağlı olabileceği düșünülmektedir. Tanenin fosfor içeriği \% 0.24-0.44 arasında değișim göstermiștir. Taban ve üst gübrelemenin yapıldığı uygulamalarda $P$ içeriğinin diğer uygulamalardan daha yüksek olduğu belirlenmiștir. Tanenin K içeriği \% 0.310.35, kalsiyum içeriği \% 0.063-0.073 ve magnezyum içeriği \% 0.043-0.064 arasında değișmiștir. Tanenin K, Ca ve Mg içerikleri açısından uygulamalar arasından fark görülmemiștir. Azotun tanenin protein içeriği üzerinde etkili olduğu Ottman vd. (2000) ve Kahraman (2006) tarafından

Çizelge 5. Farklı azotlu gübre kaynakları ve uygulama zamanlarının buğdayda tanenin bazı makro besin elementi ve protein içeriklerine etkisi

Table 5. The effects of $N$ sources fertilizer and application times on contents of macro nutrition and protein of wheat seeds

\begin{tabular}{|c|c|c|c|c|c|c|}
\hline \multirow[t]{2}{*}{ Gübre } & $\mathrm{N}$ & $\mathrm{P}$ & $\mathrm{K}$ & Ca & $\mathrm{Mg}$ & Protein \\
\hline & \multicolumn{6}{|c|}{$(\%)$} \\
\hline Kontrol & $1.90 \mathrm{e}$ & $0.24 \mathrm{e}$ & 0.32 & 0.073 & 0.043 & $12.00 \mathrm{~d}$ \\
\hline Yarım doz 20.20.0 & $2.06 \mathrm{C}$ & $0.34 \mathrm{c}$ & 0.35 & 0.073 & 0.050 & $12.90 \mathrm{c}$ \\
\hline Tam doz 20.20.0 & $2.13 \mathrm{~b}$ & $0.39 \mathrm{~b}$ & 0.35 & 0.070 & 0.053 & $13.33 \mathrm{~b}$ \\
\hline DAP & 2.27 a & 0.44 a & 0.35 & 0.063 & 0.064 & $14.20 \mathrm{a}$ \\
\hline Taban ${ }_{0}+$ Üst $N$ & $1.98 \mathrm{~d}$ & $0.30 \mathrm{~d}$ & 0.31 & 0.063 & 0.043 & $12.34 \mathrm{~d}$ \\
\hline $\operatorname{LSD}(0.05)$ & 0.062 & 0.060 & öd* & öd* & öd* & 0.398 \\
\hline
\end{tabular}

* önemli değil. 
bildirilmiștir. Müftüoğlu vd. (2003) tarafından yapılan bir çalıșmada, kompoze gübre uygulamasının tane protein içeriğini arttırdığı belirtilmiștir

\section{SONUC}

Ülkemizde gübre fiyatlarının yükseldiği yıllarda çiftçilerin gübre uygulamalarından kaçındıkları böylesi yıllarda çiftçilerin ya taban gübreleme veya üst gübrelemeden birini tercih ettikleri izlenmiștir. $\mathrm{Bu}$ yıllarda üreticilerin uygulanması gereken dozların çok altında gübre uyguladıkları da görülmüștür. Bu nedenle, bu çalıșma, uygulama zamanı ve dozları açısından optimum gübreleme yapılmaması durumunda ortaya çıkacak sonuçları izlemek için çiftçi koșullarında gerçekleștirilmiștir. Bunun için çalıșmada çiftçilerin pratikte kullandıkları gübreler ve uyguladıkları dozlar dikkate alınmıș ve uygulamalar arasındaki $\mathrm{N}$ ve $\mathrm{P}_{2} \mathrm{O}_{5}$ farklılıkları ilave gübrelerle eșitlenmemiștir.

İncelenen parametreler açısından, hem taban hem de üst gübrelemenin yapıldığı ve tam doz 20.20.0 olarak tanımlanan uygulama ile yarım doz 20.20.0 uygulamalarının daha etkin olduğu görülmüștür. Bu bağlamda DAP uygulamasının, etki bakımından 20.20.0 uygulamalarından sonra yer aldığı izlenmiștir. Bu sonucun ortaya çımmasında; bu gübrelerdeki $\mathrm{N}$ ve $\mathrm{P}_{2} \mathrm{O}_{5}$ oranlarının farkııı̆ı yanında, uygulanan gübre miktarlarına karșilık gelen $\mathrm{N}$ ve $\mathrm{P}_{2} \mathrm{O}_{5}$ miktarlarının farklı olușundan da kaynaklanabileceği düșünülmektedir. Sonuçların ortaya çıkardığı bir diğer önemli ve dikkat çekici durumun ise taban gübresi uygulamaksızın yalnızca üst gübre uygulamasının (Taban0+ÜstN) uygun verim alınması açısından yeterli olamayabileceğidir.

\section{KAYNAKLAR}

Açıkgöz N, Akbaș M E, Moghaddam A, Özcan K (1994). PC'Ier için Veritabanı Esaslı Türkçe İstatistik Paketi: TARisT, Tarla Bitkileri Kongresi: 131-136, 25-29 Nisan, İzmir.

Akman Z, Yılmaz F, Karadoğan T, Çarkçı K (1999). Isparta ekolojik koșullarına uygun yüksek verimli buğday çeșit ve hatlarının belirlenmesi. Türkiye III. Tarla Bitkileri Kongresi, Cilt:1, Genel ve Tahıllar: 366-371, 15-18 Kasım, Adana.

Altan A (1986). Tahıl İșleme Teknolojisi. Çukurova Üniversitesi Ziraat Fakültesi Ofset Atölyesi, Adana.

Anonim (2010). Devlet Meteoroloji İșleri Genel Müdürlüğü. Aydın - Söke meteorolojik verileri.

Atlı A, Koçak N, Aktan M (1999). Ülkemiz çevre koșullarının kaliteli makarnalık buğday yetiștirmeye uygunluk yönünden değerlendirilmesi. Orta Anadolu'da Hububat
Tarımının Sorunları ve Çözüm Yolları Sempozyumu: 345351. 8-11 Haziran, Konya.

Avcı R (2007). Farklı azotlu gübre uygulamalarının ekmeklik buğdayda verim ve kalite üzerine etkileri. Yüksek Lisans Tezi, Trakya Üniversitesi Fen Bilimleri Enstitüsü (Basılmamıș),Tekirdağ.

Bașar $H$, Tümsavaș Z, Katkat $A$ V, Özgümüș A (1998). Effects of various nitrogen sources and the levels of nitrogen on yield and the yield components of the wheat cultivar Saraybosna. Turkish Journal of Agriculture and Forestry, 22: 59-64.

Bremner J M (1965) Total Nitrogen In. C. A. Black (Eds.), Methods of Soil Analysis Part 2, American Society of Agronomy Inc., Madison, Wisconsin, USA, pp. 1149-1178.

Çiftçii E A, Doğan R (2013). Azotlu gübre dozlarının Gediz75 ve Flamura-85 buğday çeșitlerinde verim ve kaliteye etkisi. Tarım Bilimleri Dergisi-Journal of Agricultural Science 19:1-11.

Dogan R, Celik N, Yurur N (2008). Requirement and application frequencies of nitrogen fertilizer on bread wheat variety Arpathan-9. Asian Journal of Chemistry 20 (4): 3069 3078.

Doğan R, Yürür N (1992). Bursa yöresinde yetiștirilen buğday çeșitlerinin verim komponentleri yönünden değerlendirilmesi. Uludağ Üniversitesi Ziraat Fakültesi Dergisi, 9: 37-46.

Dokuyucu T, Cesurer L, Akkaya A (1999). Bazı ekmeklik buğday (T. aestivum L.) genotiplerinin Kahramanmaraș koșullarında verim ve verim unsurlarının incelenmesi. Türkiye III. Tarla Bitkileri Kongresi: 15-18 Kasım 1999, Adana.

Ekingezen Ș (1996). Tekirdağ ekolojik koșullarında yetiștirilen beș ekmeklik buğday çeșidinde farklı azotlu gübre dozlarının verim ve verim unsurlarına etkisi ile en ekonomik azot dozunun belirlenmesi. Yüksek Lisans Tezi, Trakya Üniversitesi Fen Bilimleri Enstitüsü (Basılmamıș), Tekirdağ.

Fageria N K, Baligar V C, Jones C A (1997). Growth and Mineral Nutrition of Fields Crops, 2nd Ed. Marcel Dekker Inc., New York, pp. 243-282.

Geçit H H, Çakır E (2006). Makarnalık buğdayda (Triticum durum L.) sulama ve azotlu gübrelemenin verim ve verim öğeleri üzerine etkisi. Tarım Bilimleri Dergisi-Journal of Agricultural Science 12 (3): 259-266.

Gençtan T, Balkan A (2006). Bazı ekmeklik buğday (Triticum aestivum L. em Thell) çeșitlerinde ana sap ve fertil kardeșlerin bitki tane verimi ve verim öğeleri yönünden karșılaștırılması. Ankara Üniversitesi Ziraat Fakültesi Tarım Bilimleri DergisiJournal of Agricultural Science, 13 (1):7-21.

Gençtan T, Sağlam N (1987). Ekim zamanı ve ekim sıklığının üç ekmeklik buğday çeșidinde verim ve verim unsurlarına etkisi. Türkiye Tahıl Sempozyumu: 171-183. 6-9 Ekim, Bursa

Jakson M L (1958). Soil Chemical Analysis. Prentice Hall, Inc.Englewood Cliffs, N. J U.S.A.

Kacar B, İnal A (2008). Bitki Analizleri. Nobel Yayın Dağıım, Ankara.

Kacar B (2009).Toprak Analizleri, 2. Baskı. Nobel Yayınları No:1387, Ankara. 
Kahraman T (2006). Bazı ekmeklik buğday çeșitlerinde farklı ekim zamanı ve azotlu gübreleme uygulamalarının, dane dolum süresi ve dane dolum oranı ile verim ve kalite unsurlarına etkilerinin belirlenmesi. Doktora Tezi, Trakya Üniversitesi Fen Bilimleri Enstitüsü (Basıımamıș), Tekirdağ

Kendal E, Tekdal S, Aktaș H, Karaman M (2012). Bazı makarnalık buğday çeșitlerinin Diyarbakır ve Adıyaman sulu koșullarında verim ve kalite parametreleri yönünden karșılaștııılması. Uludağ Üniversitesi Ziraat Fakültesi Dergisi, $26(2): 1-14$

Kırtok Y, Genç I (1980). Çukurova koșullarında değișik kökenli arpa çeșitlerinin verim ve verim unsurları üzerinde araștırmalar. TÜBITAK VII. Bilim Kongresi, TAOG Tebliğleri (Tarla Bitkileri Seksiyonu): 157-170. 6-10 Ekim, Adana.

Korkut K Z, Ünay A (1987). Tahıllarda bașak taslağı gelișimi ile verim öğeleri arasındaki ilișkiler üzerine araștırmalar. TÜBITAK, Türkiye Tahıl Sempozyumu, TOAG: 329-336. 6-9 Ekim, Bursa

Lott W L, Nery J P, Gallp J R, Medcaff J C (1956). Leaf Analysis Technique in Coffee Research. Instituto Brasileiro de Engenharia de Custos Research Inst. Bulletion No:9, Rio de Janeiro

Mut Z, Aydın N, Bayramoğlu H O, Özcan, H (2007). Bazı ekmeklik buğday (Triticum Aestivum L.) genotiplerinin verim ve bașlıca kalite özelliklerinin belirlenmesi. Ondokuz Mayıs Üniversitesi Ziraat Fakültesi Dergisi, 22 (2):193-201.

Mut Z, Aydın N, Özcan H, Bayramoğlu H O (2005). Orta Karadeniz Bölgesinde ekmeklik buğday (Triticum aestivum L.) genotiplerinin verim ve bazı kalite özelliklerinin belirlenmesi. Gazi Osman Pașa Üniversitesi Ziraat Fakültesi Dergisi: 22 (2): 85-93.

Müftüoğlu N M, Demirer T, Oktay M, Elmacı Ö L (2003). Çinko katkılı ve katkısız 15-15-15 gübre uygulamasının buğdayda verim ve bazı verim öğeleri üzerine etkisi. Atatürk Üniversitesi Ziraat Fakültesi Dergisi, 34 (4): 299-302.

Noaman M M, Taylor G A (1990). Morphophysiological characteristics, grain protein and grain yield in high and low protein winter wheat. Cereal Research Communications, 18 (1-2): 59-65.

Ottman M J, Thomas A D, Edward C M (2000). Durum grain quality as affected by nitrogen fertilization near anthesis and irrigation during grain fill. Soil Science Society of America Journal, 92: 1035-1041.
Özer M S (1998). Kepekli ekmeklerin bazı niteliklerinin incelenmesi ve kalitelerinin iyileștirilmesi olanakları. Doktora Tezi, Çukurova Üniversitesi Fen Bilimleri Enstitü (Basılmamıș), Adana.

Özkaya H, Kahveci B (1990). Tahıl ve Ürünleri Analiz Yöntemleri. Gıda Teknolojisi Derneği Yayınları No: 114. Ankara.

Özseven I, Bayram E (2005). Marmara Bölgesi'nde dört ekmeklik buğday (Triticum aestivum L.) çeșidinde değișik azot dozlarının verim ve verim unsurlarına etkilerinin belirlenmesi üzerine yapılan bir araștırma. Tarla Bitkileri Merkez Araștırma Enstitüsü Dergisi, 14 (1-2): 56-74.

Pyler E J (1988). Baking Science and Technology. Sosland Publishing Company, USA, 1345.

Sümer Ö F (2008). Ekmeklik buğday (Triticum aestivum L.) çeșitlerinde bitki sıklığı ve azot dozlarının verim, verim unsurları, agronomik ve kalite özellikleri üzerine etkileri ve özellikler arası ilișliler. Yüksek Lisans Tezi, Adnan Menderes Üniversitesi Fen Bilimleri Enstitüsü (Basılmamıș), Aydın.

Sümer-Özcan F, Erekul O, Koca Y O (2010). Farklı buğday (Triticum aestivum L.) çeșitlerinde bitki sıklığı ve azot dozlarının verim, verim öğeleri ve ekmeklik kalite özellikleri üzerine etkisi. Anadolu Journal of AARI 20 (2): 28-44.

Triboi E, Abad A, Michelena A, Lloveras J, Ollier J L, Daniel C (2000). Environmental effects on the quality of two wheat genotypes: 1. Quantitative and Qualitive Variation of Storage Proteins. European Journal of Agronomy, 13: 47-64.

Turan I (2008). Kahramanmaraș koșullarında bazı buğday, arpa ve tritikale çeșitlerinin verim ve verim özelliklerinin belirlenmesi. Yüksek Lisans Tezi, Kahramanmaraș Sütçü İmam Üniversitesi Fen Bilimleri Enstitüsü (Basılmamıș), Kahramanmaraș.

Ünal S (2002). Buğdayda kalitenin önemi ve belirlenmesinde kullanılan yöntemler. Hububat Ürünleri Teknolojisi Kongre ve Sergisi: 25-37. 3-4 Ekim, Gaziantep.

Yilmaz N (2003). A research on determining the form and the amounts of the second part nitrogenous fertilizer to be applied on wheat in spring. Pakistan Journal of Botany, 35 (4): 625-636. 